\title{
Convergent Approach to Identification of Transient States of a Dynamic System
}

\author{
V.P. Mygal*, G.V. Mygal \\ National Aerospace University "Kharkiv Aviation Institute”, 17, Chkalov St., 61070 Kharkiv, Ukraine
}

(Received 10 September 2020; revised manuscript received 16 December 2020; published online 25 December 2020)

\begin{abstract}
The article is devoted to the problem of identification of transient states of information sources (sensors, detectors, fractal biosignals, etc.) and optical media for information transmission. These states are often associated with self-organized criticality, which manifests itself near phase and structural transitions. However, the use of a variety of methods, models, patterns, parameters, indicators and criteria complicates the study of transition states. Stress factors cause temporal and spatial distortions of signals of different nature in the structure of interconnections which contains information about changes in the state of the information source. Therefore, transient states have common characteristic features, the versatility of which made it possible to implement a convergent approach to identifying transient states of information sources of different nature. The approach is based on the reconstruction of a topological 3D model from a measured scalar signal (time series, information flow). Orthogonal projections of the 3D model are the space-time signatures of the information source, which allow the analysis of the induced connections from three angles of view. Signature configurations consist of geometrically ordered sections that differ in steepness or curvature, as well as the interval between dynamic events. The characteristic features of transient states are the asymmetry of the antiphase components of the signatures and the imbalance in the powers of subsets of microstates. Visualization of 3D models and signatures of fractal signals of different nature simplifies the identification of transient states of the information source. Implementation of the approach will contribute to the effective selection of stress-resistant sensors (detectors, biosensors, etc.), as well as their monitoring.
\end{abstract}

Keywords: Complex dynamic systems, Geometrization of signals, 3D-modeling, Signal structure, Spacetime signatures, Transition states.

DOI: 10.21272/jnep.12(6).06018

PACS number: 05.10. - a

\section{INTRODUCTION}

The inevitable increase in the number of sources and carriers of information in the automation of dynamic systems (DSs) (nuclear reactors, jet engines, etc.) creates new problems [1]. In DSs, many sensors (detectors, spectrometers, etc.) and different media of information transmission are the causes of systemic problems. The use of variational principles of dynamics in modeling the functioning of a DS under normal conditions made it possible to overcome mathematical difficulties and solve some of the problems. Variational principles also contributed to the development of cybernetics [2], synergetics [3], and system dynamics [4]. The complexity of the form of signals from sensors (spectrometers, etc.) and their multidimensionality have led to the use of different processing methods and a variety of ways to display information, which limit the capabilities of cognitive graphics. In addition, the influence of external and internal stress factors on the sources and media of information transmission increases the complexity and individuality of signals (characteristics). The search for universal processing methods using information physics [5] revealed the need to identify the transition states of a DS in real time. The main goal of the work is to show the possibility of identifying the states of self-organized objects in real time by geometrizing the dynamics of their fractal signals.

\section{INDUCED COMPLEXITY}

Critical phenomena, technologies and thinking Extreme conditions bring the state of self-organized objects of different nature closer to the bifurcation point. These are transitional states that are caused by self-organized criticality [6]. Features of such states are also manifested in critical physical phenomena (phase and other transitions), technologies (smart materials) and thinking (see Fig. 1), which confirms the presence of common features (multifractality, nonlinearity, etc.).

A heuristic approach to critical physical phenomena (phase and structural transitions) contributed to the creation of critical technologies, and also identified systemic problems (cognitive [7], learning [8], etc.). Selforganization of objects of different nature is accompanied by the formation of interconnections, the structures of which have common and individual features. The complexity of the structure is due to the asymmetry of competitive processes. In particular, the dominance of positive feedback in critical technologies is used to create materials with anomalously high parameters. Whereas with the help of negative feedback they provide stability and dynamic stability of the characteristics of DS elements.

Spatial and temporal inconsistency of processes of different nature gives rise to transient states of selforganized objects, which are rather difficult to identify. At the same time, in the spatial and temporal characteristics of self-organized objects, important information is hidden about the structure of internal relationships, which is influenced by external influences. Therefore, the processes of formation and destruction of crystalline materials occur simultaneously at different scale levels, which confirms their fractal nature.

\footnotetext{
*valeriymygal@gmail.com
} 


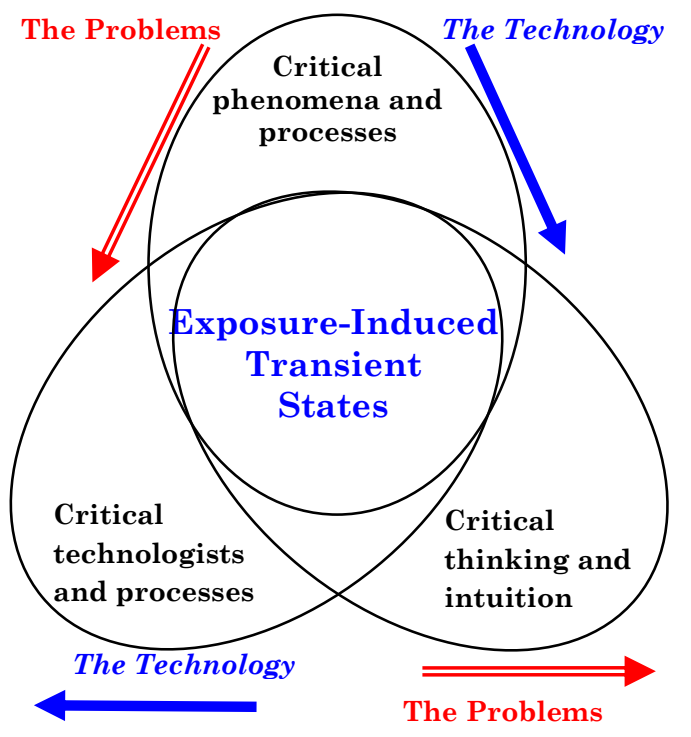

Fig. 1 - Self-organization in critical phenomena, technologies and thinking induced by exposure

Induced heterogeneities. In a real environment, heterogeneities (structure, density, composition, etc.) are sources of fields (physical, biological and informational). An intense impact on sensors and information transmission media causes self-organization of inhomogeneities to counteract external influences (Le Chatelier's principle) [9]. In this case, local distortions of signals (characteristics, parameters, information flows) arise. Hence, spatial and temporal distortions of biosignals are interrelated sources of information. They contain information about the features of the processes of excitation, self-excitation and inhibition. Induced distortions create cognitive problems (perceptions, representations, etc.). Physical analogs of the processes of excitation and self-excitation in media of information transmission are induction, self-induction and mutual induction.

The most general form of signal organization (its structure) is its spatial-temporal ordering [10]. Consideration of information interaction in terms of a force field (flow, circulation, etc.) is more effective. It allows to:

- identify sources (physical, biological and informational) by information flows;

- identify the circulation of the flow, which is created by asymmetric inhomogeneities;

- visualize sources of information.

Therefore, for the identification of transient states of sensors of different nature, the fundamental concepts of the topological, projective and metric invariant of the space-time structure, which were introduced by N. Wiener, are important.

Complementarity of the principles of natural science and biomimicry. The spatial and temporal distortions of the fractal signal contain information about the features of the structure of interconnections in the sensor. Part of the distortions are due to external stress factors that change the dynamics of the information flow, and the second part is due to internal factors. They induce inhomogeneities in the sensor, the interaction of which determines the transition states of information sources. In extreme conditions, these factors are interrelated, which limits the possibilities of mathematical modeling.

The complementarity of the extreme principles of natural science (principles of least action (Euler and others), least time (Fermat), etc.) and the principles of biomimicry underlies all natural phenomena [11]. This allows us to generalize the results of studies of objects of animate and inanimate nature. In particular, the distortion of the response of the semiconductor sensor [12] and the instability of the characteristics of biosensors [13] indicate the overlap of the fields created by the induced inhomogeneities.

The integral parameters of the sensor response are affected by static fields (thermal, electric, radiation, etc.). Whereas impulse action (electrical, acoustic and thermal shock) changes the dynamic structure of the response. In this case, the induced inhomogeneities of the sensors are manifested in spatial and temporal functional characteristics (temporal and spectral response). This duality of response increases the complexity of diagnostics of their states.

\section{CONVERGENCE OF COMPLEXITY BY MEANS OF GEOMETRIZATION}

Visualization of induced distortions. Systemic problems of technical and medical diagnostics of DS elements are associated with increasing information complexity, which is due to:

- the difference in the definitions of information (according to Wiener, Shannon, etc.) and its measure [5];

- the distortion of information during processing and a variety of types of visualization;

- fractality of signals (responses of smart sensors, electrophysiological signals, etc.).

Spatial inhomogeneities of the information transmission medium also distort flows of different nature. This allows us to consider local distortions as universal sources of information. Geometrization has always played the role of a "generator of revolutionary ideas" in natural science. Consequently, the visualization of information flows in one space will reveal the transition states of the DS elements. In this case, the identification of transient states can be carried out by geometrizing fractal signals based on convergence:

- N. Wiener's ideas about the spatial-temporal ordering of the signal structure [10], which underlies cybernetics and brain functioning [14];

- ideas of model reconstruction from a 1D measured signal (Packard, 1980 [15]), which was formalized by Takens [16];

- principles of system dynamics of complex systems, which allow simulating connections, feedback loops and response delays [17].

The complementarity of the above ideas and principles is heuristic. So, the combination of ideas of nano-, bio, information and cognitive technologies [18] gave impetus to the development of 3D-modeling, 3Ddesign, and 3D-technologies. At the same time, the creation of natural and artificial 3D nanostructures with unique characteristics and high parameters showed the fundamental possibility of solving the inverse problem the reconstruction of a $3 \mathrm{D}$ model using a measured $1 \mathrm{D}$ 
temporal fractal signal. This is facilitated by:

- complementarity of the principles of least action (Hamilton and A. Hertz) and the principles of biomimicry that underlie natural phenomena;

- geometrization of the Jacobi principle of least action in the form of a geodesic curve;

- energetic interpretation of the Gauss principle of least compulsion and its connection with E. Noether's theorem.

Reconstruction of the topological $3 D$ model from the measured time signal. The complementarity of extreme principles is most pronounced in the parametric space of dynamic events (state-speedacceleration) [19]. The manifestation of the cognitive aspects of information interaction indicates the polydisciplinarity of the space of dynamic events [7]. Application of variational principles and principles of feedback made it possible to reveal the cycle of selfreproduction of the fractal structure of the electrophysiological signal. On the basis of this cycle, a nature-like algorithm was developed, which made it possible to reconstruct a 3D model using the measured signal.

Orthogonal projections of a 3D model of a fractal signal are a natural decomposition into interrelated dynamic, energetic and structural features of the information source. In turn, the configuration of each projection reflects the decomposition into the following components:

- geometrically ordered sections that differ in steepness (speed) or curvature (acceleration);

- subsets of dynamic events that differ in time intervals between events and reflect the multidimensionality of time;

- subsets of microstates, the powers of which are proportional to the entropy of the main phases of the signal [19].

Space-time signatures. Using the example of configurations of space-time signatures of a cardiac cycle of the 1st and 2nd orders, let us consider the natural decomposition into opposite components (phases, subsets, extrema, etc.) (Fig. 2a). In this case, the configuration of the 1 st order cardiac cycle signature (Fig. 2a, plane a) reflects the sequence of dynamic events, which coincides with the sequence of dynamic states in the cardiac cycle, i.e. with its phase portrait. Analysis of the phase portrait in space (state speed - time) (Fig. 2b) is clear, and the analysis of the signature is more informative. In our opinion, the fundamental indistinguishability of dynamic states and events limits the capabilities of artificial intelligence.

As can be seen from the figure, signature configurations display information flow in two ways - dynamically and statistically. The projections of the 3D model of the cardiocycle display the spatial-temporal signatures of the 1st and 2nd orders, the analysis of which provides complementary information about the dynamic, energetic and informational individuality of the cardiocycle. The main thing is that convergence allows it to be analyzed in real time.

In general, the signatures of the 1 st and 2 nd orders are natural geometric models of the signal, which makes it possible to identify the transition states by its dynamic, energy and informational characteristics [20].

\section{D model and its projections}

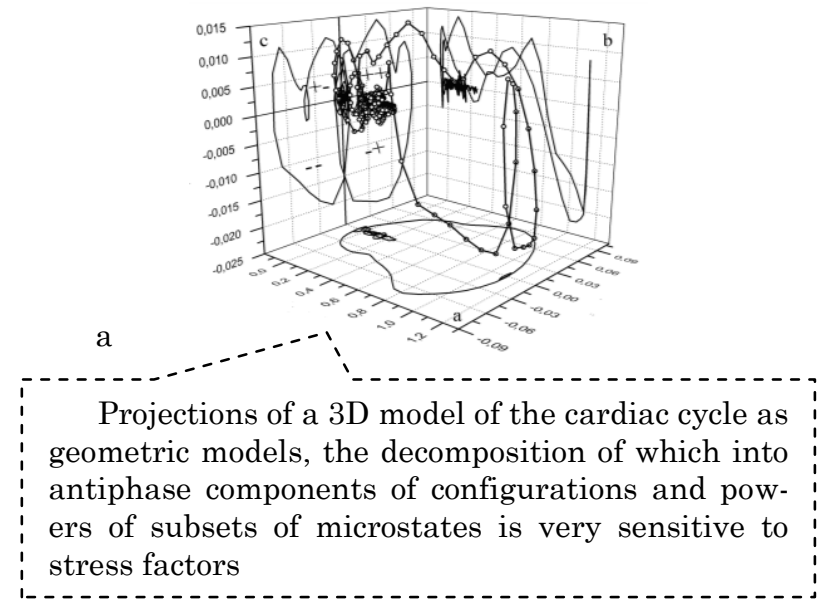

Phase portrait

$\mathrm{b}$

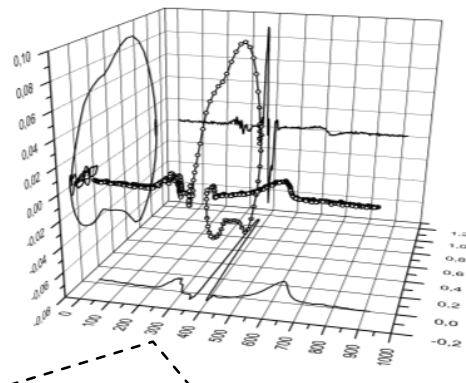

Integrative indicators of the state of the heart (the area of the portrait and the length of its contour) are not sensitive to stress factors

Fig. 2 - Human cardiosignal as a trajectory of dynamic events (a), as well as a sequence of dynamic states (b)

Thus, with the help of a convergent approach, markers of transient states, which are technologically inherited, have been identified in the signals of sensors (detectors, spectrometers, etc.). Therefore, the atlas of signatures of fractal signals of different nature has great innovative potential.

\section{CONCLUSIONS}

The difficulty in identifying the transition states of active and passive media is due to induced inhomogeneities of different nature. They create spatial and temporal distortions of information flows, the geometrization of which in the space of dynamic events to reveal the sources of relevant information about the transition states of elements of a DS. The convergent approach to the identification of transient states of sources and media of information transmission made it possible to identify:

- relationships between macrostate and microstate power, order and disorder, balance and imbalance in real time;

- a multifractal structure of transient electrophysiological signals;

- a fine structure of fractal signals of different nature, which determines their information complexity. 
The space-time structure of dynamic processes of different nature is geometrically similar. Therefore, the creation of an atlas of spatial-temporal signatures of fractal signals of self-organized objects will facilitate the effective selection of sensors, detectors, spectrometers and other relevant sources of information. The atlas will allow to carry out technical diagnostics and medical diagnostics in real time. A convergent approach to identifying transients will simplify their classification, which will expand the capabilities of machine learning and predictive analytics.

\title{
REFERENCES
}

1. V. Mygal, G. Mygal, Information \& Security: An International Journal 43, No 2, 134 (2019).

2. S. Beer, Cybernetics and Management. London (1959).

3. H. Haken: Advanced Synergetics: Instability Hierarchies of Self-Organizing Systems and Devices (New York: SpringerVerlag: 1993).

4. J. Forrester, System Dynamics Review 23 Iss. 2-3, 345 (2007).

5. G.V. Vstovskij, Elementy informaczionnoj fiziki (Elements of information physics). M.: MGIU (2002).

6. P. Bak, C. Tang, K. Wiesenfeld, Phys. Rev. 38, No 1, 364 (1988).

7. V.P. Mygal, G.V. Mygal, L.M. Balabanova, J. Nano- Electron. Phys. 11, No 2, 02013 (2019).

8. V.P. Mygal, H.V. Mygal, Radioelectronic and computer systems 1(93), 90 (2020).

9. D.J. Evans, D.J. Searles, E. Mittag, Phys. Rev. 63, 051105 (2001).

10. N. Viner, Kibernetika, ili Upravlenie $i$ svyaz $v$ jivotnom $i$ mashine (Moskva: Nauka: 1983).

11. Kevin M. Passino, Biomimicry for Optimization, Control, and Automation (Springer-Verlag: 2005).

12. V.P. Migal, I.A. Klymenko, G.V. Migal, Functional Materials 24(2), 212 (2017).

13. V.P. Migal, I.A. Klymenko, G.V. Migal, Functional Materials 24(2), 212 (2017)

14. H. Haken, Principles of Brain Functioning. A Synergetic Approach to Brain Activity, Behavior and Cognition. (SpringerVerlag Berlin Heidelberg).

15. N. Packard, J. Crutchfield, J. Farmer, R. Shaw, Phys. Rev. Lett. 45, 712 (1980)

16. F. Takens, Nonlinear dynamics and turbulence. N.Y., Pitman, 314 (1983).

17. M. Schwaninger, J. Ríos, System Dynamics Review 24, No 2, 145 (2008)

18. M. Roco, W. Bainbridge, Converging Technologies for Improving Human Performance: Nanotechnology, Biotechnology, Information Technology and Cognitive Science. [Electronic resource] Access mode.

19. V.P. Mygal, A.V. But, G.V. Mygal, I.A. Klimenko, Sci. Rep. 6, 387 (2016)

20. V.P. Mygal, G.V. Mygal, Dependable Systems, Services and Technologies, DESSERT, 224 (Ukraine: Kyiv: 2020).

\section{Конвергентний підхід до ідентифікації перехідних станів динамічної системи}

\author{
В.П. Мигаль, Г.В. Мигаль
}

Національний аерокосмічний університет ілені М.Є. Жуковського "Харківський авіаційний інститут", вул. Чкалова, 17, 61070 Харків, Україна

Стаття присвячена проблемі ідентифікації перехідних станів джерел інформації (датчиків, детекторів, фрактальних біосигналів тощо) та оптичних носіїв для передачі інформації. Ці стани часто асоціюються з самоорганізованою критичністю, яка проявляеться поблизу фазових та структурних переходів. Однак використання різноманітних методів, моделей, паттернів, параметрів, показників та критеріїв ускладнюе дослідження перехідних станів. Стресові фактори викликають спотворення сигналів різної природи в часі та просторі, структура взаємозв'язків яких містить інформацію про зміни стану джерела інформації. Тому перехідні стани мають спільні характерні ознаки, універсальність яких дала можливість застосувати конвергентний підхід до ідентифікації перехідних станів джерел інформації різної природи. В основі підходу - реконструкція топологічної тривимірної моделі за вимі ряним скалярним сигналом (зміна параметру в часі, інформаційний потік). Ортогональні проекції тривимірної моделі - це просторово-часові сигнатури джерела інформації, які дозволяють аналізувати індуковані зв'язки з трьох кутів зору. Конфігурації сигнатур складаються з геометрично впорядкованих ділянок, які відрізняються крутизною або кривиною, а також інтервалом між динамічними подіями. Характерними ознаками перехідних станів е асиметрія антифазних компонентів сигнатур та дисбаланс потужностей підмножин мікростанів. Візуалізація тривимірних моделей та сигнатур фрактальних сигналів різної природи спрощуе ідентифікацію перехідних станів джерела інформації. Впровадження підходу сприятиме ефективному вибору стійких до стресів датчиків (детекторів, біосенсорів тощо), а також їх моніторингу.

Ключові слова: Складні динамічні системи, Геометризація сигналів, 3D-моделювання, Структура сигналу, Просторово-часові сигнатури, Перехідні стани. 